\title{
Seed yield and quality as influenced by growing conditions in hybrid seed production of bitter gourd (Momordica charantia L.) cv. Pusa Hybrid-1
}

\author{
G. S. Jat ${ }^{{ }^{*}}$, Balraj Singh ${ }^{2}$, B. S. Tomar ${ }^{1}$, Jogendra Singh ${ }^{1}$, Hanuman Ram ${ }^{1}$ and Mukul Kumar ${ }^{3}$ \\ ${ }^{1}$ Division of Vegetable Science, Indian Agricultural Research Institute, New Delhi-110012, INDIA \\ ${ }^{2}$ Agriculture University, Jodhpur-342001 (Rajasthan), INDIA \\ ${ }^{3}$ Krishi Vigyan Kendra, Raisen-464551 (M.P.), INDIA \\ *Corresponding author. E-mail: singhgograj@gmail.com
}

Received: February 22, 2016; Revised received: August 25, 2016; Accepted: November 14, 2016

\begin{abstract}
The present investigation was carried out under insect proof net house (IPN) and open field condition (OFC) at Centre for Protected Cultivation Technology and Seed Testing Laboratory of Division of Seed Science \&Technology, IARI, New Delhi in bitter gourd cv. Pusa Hybrid-1 during summer season because under open field condition the seed yield and seed quality of bitter gourd drastically reduced due to viral diseases and fruit fly in kharif and early onset of high temperature, unseasonal rains during summer, which restricts the hybrid seed production of bitter gourd under north Indian condition. The observations on seed yield \& quality characters and physical properties of seed were recorded. The quality attributes were evaluated immediately after harvest and after 8 months of ambient storage and their results were compared. The experimental results revealed that total number of seed per fruit (46.7), number of filled seed per fruit (45.3), seed yield per fruit (9.41g), seed yield per plant (27.28g), and seed yield per hectare $(232 \mathrm{~kg})$ were significantly higher under IPN in comparison to OFC. Among the physical parameters of seed, seed width $(0.81 \mathrm{~cm})$ \& seed coat $(0.79 \mathrm{~g})$ weight recorded significantly higher in IPN. The seed quality attributes immediately after harvest was also significantly superior under IPN compared to OFC except for germination \%. The hybrid seed produced under IPN conditions could maintain their superiority for quality traits even after 8 months of its ambient storage. The seed yield and seed quality attributes were comparatively superior under IPN conditions. The seed crop grown under IPN overcomes the threat of insect vectors, viral diseases and unfavourable climatic conditions and helps in attaining the better seed yield and quality.
\end{abstract}

Keywords: Insect proof net house, Open field, Seed Quality, Seed yield

\section{INTRODUCTION}

Momordica charantia L. $(2 \mathrm{x}=2 \mathrm{n}=22)$, commonly known as bitter gourd or bitter melon, is an economically important member of cucurbitaceae family, cultivated in India, China, Malaysia, Africa, and South America (Miniraj et al., 1993). Compared with other cucurbitaceous crops, it is highly valuable for its nutritive content like proteins, carbohydrates, vitamins, and minerals primarily ascorbic acid and iron (Behera et al., 2004; Miniraj et al., 1993), as well as various medicinal properties (Alam et al., 2009). The fruit and juice have been used as treating diabetes (Baynes et al., 1995). It can be grown in both seasons for commercial production, but seed production, especially hybrid seed production which requires vigorous growth, higher number of female flower, higher fruit set, better fruit development and maturation in seed parent (Basu et al., 2013). Hybrid seed production under north Indian condition cannot be organised successfully in open field condition because of high incidence of viral diseases and white fly attack in kharif season. Besides this, in spring summer the plant growth and development are greatly affected by chang- ing environmental conditions, early onset of high temperature, unseasonal rains during summer (April-June), sudden increase in temperature hamper the production of female flower, fruit set and fruit development, resulting in low seed yield and seed quality. Thus, attaining economic yield is a difficult task in hybrid seed production under north Indian condition. The seed crop grown under IPN overcomes the threat of insect vectors, viral diseases and unfavourable climatic conditions (Flemine X. et al., 2012). In order to ensure better quality and higher seed yield the present investigation was planned and undertaken with the objectives to compare the effect of growing conditions on the seed yield and seed quality contributing characters including physical properties of seed immediately after harvest and after 8 months of ambient storage.

\section{MATERIALS AND METHODS}

The present experiment was carried out during MarchMay, 2010 at CPCT farm, IARI, New Delhi, India under two growing conditions viz. IPN and OFC. The insect proof net is made up of UV stabilized white colour, 40 wire mesh insect proof nylon net, with dou- 
ble door facility and having dimensions $60 \mathrm{~m} \times 6 \mathrm{~m} \times$ $2 \mathrm{~m}$. Drip fertigation facilities were laid in both the growing conditions. The experimental material consists of parental line of bitter gourd hybrid Pusa Hybrid -1 . The seeds of parental lines were obtained from the Division of Vegetable Science, IARI New Delhi. The seedlings of parental lines were raised in $1 \frac{1}{2}$ " size conical plug tray with soil-less medium in a modern nursery at CPCT farm. After seed sowing the plug trays were placed in the germination room at a temperature of $20^{\circ} \mathrm{C}$ and relative humidity at around $100 \%$. Twenty days old seedlings of both parental lines were transplanted in the ratio of 3:1 ( 3 female line: 1 male line) following block method on raised beds under both conditions. The total numbers of female plants were 180 and male plants 60 under IPN and same number of female and male plants were also planted in OFC. Thirty plants were randomly selected in seed parent as well as pollen parent under both growing condition for recording observations. All the recommended agronomic practices were followed to raise a healthy crop. The male flowers in seed parent were pinched off regularly before the anthesis and the female flowers likely to be opened on next day were covered with white butter paper bag during evening $(5-7 \mathrm{pm})$ to avoid out crossing or sib pollination. The male buds from pollen parents were protected and collected in early morning on next day and pollination was performed through hand pollination (Tomar et al., 2009, Vishwanath, 2007). The meteorological observations on temperature, relative humidity and light intensity were recorded during the entire period of experiment (Table1) and during flowering period of the crop on weekly basis (Table2). The mature (bright yellow coloured) fruits were harvested and seeds were extracted manually. The mucilage of the seeds was removed by rubbing the seeds with sand followed by washing with running water. The seeds were dried separately under shade for one day followed by sun light. The observations on number of seeds per fruit, number of filled seeds per fruit and number of unfilled seed per fruit were carried out by counting the seeds. The seed yield per fruit and seed yield per plant were calculated using an electronic weighing balance of $0.001 \mathrm{~g}$ precision, 100 seed weight was recorded by counting 100 seeds of mixed 3-5 fruit seeds from harvested fruits and weight was recorded. The seed length and width were calculated by averaging the length and width of ten randomly selected seeds. The seed length and seed width were counted by using graph paper technique. The cotyledon weight and seed coat weight were calculated after removing the seed coat of ten randomly selected seeds from each harvested fruits and weighing separately using an electronic balance.

The observations for germination $\%$ were carried out at Seed Testing Laboratory, Division of Seed Science \& Technology, IARI, New Delhi following the International Seed Testing Association (ISTA) procedure. The electrical conductivity was measured using a digital conductivity meter (Dadlani and Agrawal, 1987). Ten normal seedlings were randomly selected for measuring seedling length. The root length (from collar region to tip of root) and shoot length (from collar region to tip of shoot) were taken and were added to get the seedling length and the average of ten seedling length was calculated and expressed in $\mathrm{cm}$. The fresh weight of seedlings was calculated by recording the fresh weight of ten normal seedlings from each harvested fruits. Seedlings dry weight was calculated by drying the ten seedlings covered with butter paper for 48 hours in hot air oven maintained at $60^{\circ} \mathrm{C}$. Seed vigour index-I was calculated using the procedure suggested by Abdul Baki and Anderson, 1973 and expressed in whole number. The quantitative data generated were analysed statistically for testing the heterogeneity of means adopting the $t$ - test procedures. The probability was worked out at $5 \%(p=0.05)$ wherever $t$ - value is nonsignificant, it is denoted by NS.

\section{RESULTS AND DISCUSSION}

Seed yield contributing characters: Seed yield is a multifaceted characteristic influenced by number of seeds / fruit, seed yield / plant, seed yield / hectare and also by environmental factors as well as the growing conditions. The observations for number of seeds per fruit showed significant difference between growing conditions. The number of seeds / fruit (46.70), number of filled seeds / fruit (45.30) was significantly higher in IPN than under OFC. A significant difference was also observed for number of unfilled seeds / fruits which were only 1.40 in IPN than 3.70 under OFC (Table 3). A highly significant difference was recorded for seed yield / fruit (9.41g), seed yield per plant $(27.28 \mathrm{~g})$, seed yield per hectare $(232 \mathrm{Kg})$ in IPN comparison to OFC and it may be due to the higher pollen viability and better post fertilization growth and devel-

Table 1. Mean monthly meteorological data during crop duration (February - May, 2010).

\begin{tabular}{|c|c|c|c|c|c|c|c|c|c|c|}
\hline \multirow[t]{2}{*}{ Month } & \multicolumn{3}{|c|}{ Temperature $\left({ }^{0} \mathrm{C}\right)$} & \multicolumn{3}{|c|}{ Relative humidity (\%) } & \multirow{2}{*}{$\begin{array}{l}\text { Total rain } \\
\text { (mm) }\end{array}$} & \multirow{2}{*}{$\begin{array}{l}\text { Wind speed } \\
\text { (Kmph) }\end{array}$} & \multirow{2}{*}{$\begin{array}{c}\text { Sun shine } \\
\text { (hrs) }\end{array}$} & \multirow{2}{*}{$\begin{array}{c}\text { Evaporation } \\
(\mathrm{mm})\end{array}$} \\
\hline & Max & Min & Mean & Max & Min & Mean & & & & \\
\hline Feb & 23.6 & 11.3 & 17.4 & 87.9 & 37.9 & 62.9 & 6.1 & 2.2 & 7.6 & 2.1 \\
\hline Mar & 30.9 & 14.5 & 22.7 & 79.0 & 30.1 & 54.5 & 4.0 & 1.6 & 7.9 & 4.9 \\
\hline April & 36.1 & 21.3 & 28.7 & 45.5 & 24.3 & 34.9 & 1.8 & 4.9 & 8.9 & 8.0 \\
\hline May & 38.3 & 24.2 & 31.2 & 54.3 & 36.2 & 45.2 & 30.4 & 4.7 & 11.7 & 9.7 \\
\hline
\end{tabular}

Source: Centre for Protected Cultivation Technology, IARI, New Delhi. 
Table 2. Weather conditions during flowering period of the crop (average on weekly basis during April, 2010).

\begin{tabular}{|c|c|c|c|c|c|c|c|}
\hline \multirow{2}{*}{ Growing conditions } & \multicolumn{3}{|c|}{ Temperature $\left({ }^{0} \mathrm{C}\right)$} & \multicolumn{3}{|c|}{ Relative humidity (\%) } & \multirow{2}{*}{$\begin{array}{l}\text { Light intense } \\
\text { ( lux ) }\end{array}$} \\
\hline & Max & Min & Mean & Max & Min & Mean & \\
\hline \multicolumn{8}{|l|}{ Insect proof net house } \\
\hline First week & 27.0 & 16.2 & 21.6 & 74.0 & 21.6 & 47.8 & $436 \times 100$ \\
\hline Second week & 33.1 & 17.9 & 25.5 & 47.5 & 29.3 & 38.4 & $400 \times 100$ \\
\hline Third week & 34.4 & 22.0 & 28.2 & 48.4 & 22.1 & 35.2 & $406 \times 100$ \\
\hline Fourth week & 36.1 & 26.1 & 31.1 & 36.9 & 20.8 & 28.8 & $430 \times 100$ \\
\hline \multicolumn{8}{|l|}{ Open field } \\
\hline First week & 28.7 & 16.9 & 22.8 & 68.9 & 23.5 & 46.2 & $494 \times 100$ \\
\hline Second week & 35.1 & 18.4 & 26.7 & 44.8 & 26.1 & 35.7 & $798 \times 100$ \\
\hline Third week & 35.4 & 22.8 & 29.1 & 45.9 & 22.8 & 34.3 & $770 \times 100$ \\
\hline Fourth week & 37.7 & 27.9 & 32.8 & 36.7 & 22.6 & 29.8 & $803 \times 100$ \\
\hline
\end{tabular}

Table 3. Effect of growing conditions on seed yield and physical properties of seeds of bitter gourd cv. Pusa Hybrid-1 during summer season (Feb- May, 2010).

\begin{tabular}{lccc}
\hline \multicolumn{1}{c}{ Characters } & IPN & OFC & Level of significance \\
\hline Number of seeds per fruit & 46.70 & 23.80 & $* *$ \\
Number of filled seeds per fruit & 45.30 & 20.10 & $* *$ \\
Number of unfilled seeds per fruit & 1.40 & 3.70 & $* *$ \\
Seed yield per fruit (g) & 9.41 & 4.81 & $* *$ \\
Seed yield per plant (g) & 27.28 & 7.29 & $* *$ \\
Seed yield per hectare (kg) & 232.00 & 54.00 & $\mathrm{NS}$ \\
100 seed weight (g) & 14.80 & 13.80 & $\mathrm{NS}$ \\
Seed length (cm) & 1.40 & 1.35 & $* *$ \\
Seed width (cm) & 0.81 & 0.75 & $* *$ \\
Seed coat weight (g) & 0.79 & 0.58 & $\mathrm{NS}$ \\
Cotyledon weight (g) & 0.79 & 0.81 & \\
\hline
\end{tabular}

NS non-significant, * Significant at $\mathrm{P}=0.05, \quad * *$ Significant at $\mathrm{P}=0.01$, IPN-Insect Proof Net house, OFC-Open Field Condition.

Table 4. Effect of growing conditions on seed quality characters immediately after harvest and eight of ambient storage of bitter gourd cv. Pusa Hybrid-1.

\begin{tabular}{lccc}
\hline Characters & IPN & OFC & Level of significance \\
\hline Electrical conductivity (ds/m) & 0.13 & 0.18 & $* *$ \\
Germination (\%) & 98 & 98 & NS \\
Seedling length (cm) & 36.68 & 22.18 & $*$ \\
Seedling fresh weight (g) & 11.81 & 10.111 & $*$ \\
Seedling dry weight ( mg) & 1.034 & 0.8214 & $* *$ \\
Seed vigour index I & 3594.60 & 2112.88 & $* *$ \\
Seed vigour index II & 101.332 & 80.495 & NS \\
Germination (\%) & 98 & 98 & $* *$ \\
Seedling length (cm) & 32.52 & 22.52 & NS \\
Seedling fresh weight (g) & 9.683 & 9.382 & $* *$ \\
Seedling dry weight ( mg) & 0.94 & 0.80 & $* *$ \\
Seed vigour index I & 3186.96 & 2206.96 & $* *$ \\
Seed vigour index II & 92.61 & 78.30 & \\
\hline
\end{tabular}

NS non-significant, * Significant at $\mathrm{P}=0.05, \quad * *$ Significant at $\mathrm{P}=0.01$, IPN-Insect Proof Net house, OFC-Open Field Condition.

opment of the fruits and is in agreement with the result obtained in multiplication of parental lines of pumpkin under IPN (Singh et al., 2009; Flemine et al., 2012; Basu et al., 2013). Shade house conditions are more favourable for higher seed yield and quality (Yadav and Malabasari, 2014). Highly significant differences in seed yield/fruit, seed yield/plant under IPN were due to higher number of filled seed/fruit and number of matured fruit/plant. Though 100 seed weight showed non-significant difference in both growing conditions, but it was numerically higher in IPN $(14.80 \mathrm{~g})$ com- pared to OFC (13.80g) and it could be due to size grading of seeds (Table 3).

Physical properties of seed: The observations on seed length and cotyledon weight showed non-significant difference under both growing conditions, but seed width showed significant difference, it was $0.81 \mathrm{~cm}$ in IPN and $0.75 \mathrm{~cm}$ in OFC. The observations for seed coat weight showed significantly higher difference, it was $0.79 \mathrm{~g}$ in IPN comparison to OFC $(0.58 \mathrm{~g})$ (Table 3 ). Among the physical parameters, seed width and seed coat weight have shown significant difference and 
were higher in IPN and may be due to the better development and maturation of fruit under IPN because of more fruit width and fruit length and it may be because of better photosynthetic efficiency of plant in comparison to OFC and increased quantity of chlorophyll (Collard et al., 1977; El-Aidy, 1983) where as in OFC it was affected by incidence of viruses and higher light intensity.

Seed quality attributes immediately after harvest: The observed value for electrical conductivity was significantly lower in IPN $(0.13 \mathrm{ds} / \mathrm{m})$ than OFC $(0.18 \mathrm{ds} / \mathrm{m})$ which indicates the sound development of seed and considered to be highest quality seeds. A nonsignificant difference was recorded for germination percentage which was $98 \%$ under both growing conditions immediately after harvest, but seedling length was significantly higher in IPN $(36.68 \mathrm{~cm})$ compared to OFC $(22.18 \mathrm{~cm})$ (Table 4). A significant difference was recorded for seedling fresh weight, which was higher in IPN (11.81g) than OFC (10.11g). Seedling dry weight was also significantly higher in IPN $(1.03 \mathrm{mg})$ compared with OFC $(0.82 \mathrm{mg})$. A highly significant difference was recorded for seed vigour index-I, which was superior in IPN (3594.60) in comparison with open field conditions (2112.88). Similarly seed vigour index II showed significantly higher difference under IPN (101.33) than in OFC (80.49) (Table 4). Similarly the seed quality attributes under insect proof net house, immediately after harvest was significantly superior over open field seed crop (Anonymous, 2008). Poly house conditions are more favourable for higher hybrid seed yield and seed quality in bottle gourd (Pham et al., 2007). Insect proof net house condition is highly suitable for quality seed production of brinjal in north Indian plains (Singh et al., 2006).

Seed quality attributes after eight month of ambient storage condition of seeds: After eight month of ambient storage of seeds there was non-significant difference for germination percentage which was $98 \%$ under both growing conditions. A highly significant difference was recorded for seedling length and it was $32.52 \mathrm{~cm}$ in IPN and $22.52 \mathrm{~cm}$ in OFC, but for seedling fresh weight, a non-significant difference was recorded, it was $9.68 \mathrm{~g}$ in IPN and $9.38 \mathrm{~g}$ under OFC. Highly significantly difference was recorded for seedling dry weight in IPN $(0.94 \mathrm{mg})$ compared to OFC $(0.80 \mathrm{mg})$. A highly significant difference was noticed for seed vigour index-I in IPN (3186.96) in comparison to OFC (2206.96). Similarly for seed vigour index-II, highly significant difference was recorded between IPN (92.61) and OFC (78.30) (Table 4). In pumpkin seed yield/fruit, seed yield/plant, seed yield/ha, seed width, seed coat weight and seed quality attributes were also significantly higher under insect proof net house immediately after harvest as well as after 8 months of ambient storage in comparison to open field, (Xavier, 2010). The seed quality is normally judged by germination percentage, seed vigour index and electrical conductivity of the seed. The observations for seedling length, fresh seedling weight and dry seedling weight were significantly higher under IPN in comparison to $\mathrm{OFC}$, may be due to the higher photosynthetic efficiency and better assimilation of food reserve in seed. Similarly the electric conductivity of the seeds obtained from IPN was significantly lower than open field crop, has indicated the sound development of seed. The seed production carried out under IPN conditions showed better performance even after eight months of ambient storage except for germination percentage and fresh seedling weight which had shown non-significant differences.

\section{Conclusion}

It was concluded that seed yield and seed quality characters including physical parameters of seed i.e. number of seed per fruit (46.7), number of filled seed per fruit (45.3), seed yield per fruit (9.41g), seed yield per plant $(27.28 \mathrm{~g})$, and seed yield per hectare $(232 \mathrm{~kg})$ were significantly higher under IPN in comparison to OFC were significantly superior under IPN over open field grown crop. The seed quality attributes immediately after harvest of the seeds as well as after 8 months of its ambient storage could maintain their superiority. This superior performance of seed yield and seed quality under IPN showed that the use of IPN in bitter gourd hybrid seed production could be quite effective in reducing the incidence of virus and other insects pests like whiteflies, leaf miners etc. Thus, it is quite clear that hybrid seed production of bitter gourd could be done under insect proof net house for obtaining maximum seed yield, seed quality and economic returns during summer under North Indian plains.

\section{REFERENCES}

Abdul-Baki, A.A. and Anderson, J.D. (1973). Vigour determination in soybean by multiple criteria. Crop science, 13: $630-637$

Alam, S. Asad, M. Asdaq, S.M. and Prasad, V.S. (2009). Antiulcer activity of methanolic extract of Momordica charantia L. in rats. J. of Ethnopharmacology, 123: 464 $-469$

Anonymous (2008c) Indian Agricultural Research Institute, Annual Report 2007- 08 pp 35

Collard, R.C. Joiner, J.N. Conover C.A. and Mc Connell, D.B. (1977). Influence of shade and fertilizer on light compensation point Ficus benjamina L. J. of American Society of Horticultural Science, (24) 447-449

Basu, S., Singh, S., Nagamani, S., Lal, S.K., Joshi, M.A. and Singh, B. (2013). Studies on hybrid seed production of bitter gourd under insect proof net house. Proceedings of XIII ISST National Seed Seminar on Innovations in Seed Research and Development, 8-10 June 2013, Bengaluru, $\mathrm{p} 46$

Baynes, J.W. (1995). Mechanistic approach to diabetes (2nd ed., pp. 203-231). Chichester, UK: Ellis Harwood Limited Behera, T.K. (2004). Heterosis in bitter gourd. In Singh, P.K., Dasgupta, S.K. and Tripathi, S.K. (Eds.), 
Hybrid vegetable development (pp. 217-221). NY: The Haworth Press.

Dadlani, M. and Agrawal, P.K. (1987). Techniques in seed science and technology, South Asian Publishers, New Delhi, pp 103-104

El-Aidy, F., Moustafa, S. and El-Afry. (1983). Influence of shade on growth and yield of tomatoes cultivated in summer season in Egypt. Plasticulture, (59) 33-36

Flemine, X., Singh, B. and Tomar, B.S. (2012). Effect of growing conditions on growth, flowering behaviour and seed yield of parental lines of pumpkin (Cucurbita moschata) cv. Pusa Hybrid-I. Seed Research, 40 (2): 118-23

Miniraj, N., Prasanna, K.P. and Peter, K.V. (1993). Bitter gourd (Momordica spp.) In Kalloo, G. and Bergh, B.O. (Eds.), Genetic improvement of vegetable plants (pp. 239-246) Oxford: Pergamon Press.

Pham, D.T. Tomar, B.S. and Singh, B. (2007) Producing hybrid seed of bottle gourd. Indian Horticulture, 52(1) 13-5

Singh, B. and Tomar, B.S. (2006). Quality seed production of vegetables under protected conditions. (In) Proceedings of XII National Seminar, 24-26 February 2006, Hyderabad, Telangana, pp 42

Singh, B., Tomar, B.S. and Thakur, Shailja. (2009). Quality seed production of parental lines of Pumpkin under insect proof net house. Paper presented in $4^{\text {th }}$ International Cucurbitaceae Symposium held at HUNAN, China, September, 21-26, 2009

Tomar, B.S., Pham, D., Singh, B. and Kalyanrao. (2009). Studies on Methods of pollination for hybrid seed production in bottle gourd. Seed Research, 37 (1\&2) 171174

Vishwanath, (2007) Studies on floral attributes and methods of pollination on seed yield and quality in pumpkin (Cucurbita moschata Dutch ExPloir) cv. Pusa hybrid-1, Msc Thesis, P.G. School, IARI, New Delhi.

Xavier, F. (2010). Studies on hybrid seed production in pumpkin under insect proof net house and open field conditions. M Sc. Thesis, Indian Agriculture Research Institute, New Delhi-110012

Yadav, S.S. and Malabasari, T.A. (2014). Effect of period of pollen storage and pollination day after flower opening on fruit set and seed yield in bitter gourd (Momordica charantia L.) under shade house. Research and Reviews: Journal of Agriculture and Allied Sciences, 3(4): 136 